\title{
Verifying the prevalence of PET plastic in food packaging and testing its leachability to antimony (Sb) in bottled drinking water
}

\author{
Al-Ser A. Al-Khatim and Mohamed H. Shiboob \\ Department of Environmental Health Sciences, Faculty of Meteorology, Environment and Arid \\ Land Agriculture, King Abdulaziz University, Jeddah, Kingdom of Saudi Arabia.
}

\begin{abstract}
Nowadays, polyethylene terephthalate (PET) is the plastic of choice in food packaging worldwide. There are claims describing PET as a safe and unleachable plastic. In this study, prevalence of PET in Jeddah city was first investigated, where 156 different food products packaged in plastics, were examined in a number of major superstores to classify their plastics through their plastic identification code (from 1 to 7), imprinted on each plastic package. Analyzed data signified PET as the prevalent type (42.95\%), followed by PP and HDPE (20.51\%, 17.31\%, respectively). PS, O (other), LDPE, and PVC were the least common types $(4.49 \%, 2.56 \%, 1.28 \%$ and $0.64 \%$, respectively). More than $10 \%$ of the examined items were codeless and, hence, could not be identified. PET leachability was further tested for the heavy metal antimony ( $\mathrm{Sb}$ ) (used in PET fabrication) in bottled drinking water ( 8 brands) under 6month storage conditions: room temperature $\left(23^{\circ} \mathrm{C}\right)$ and incubator $\left(50^{\circ} \mathrm{C}\right)$, both of which have indicated highly significant $(\mathrm{p} \leq 0.0001)$ effects on the $\mathrm{Sb}$ level, compared with time-zero concentration (initial).
\end{abstract}

Keywords: health effects, packaging, PET-bottled water, PET prevalence, Plastics' types, Sb leachability.

\section{Introduction}

Plastics continue to benefit society in innumerable applications, even though research has proved their adverse health and environmental impacts. These synthetic materials are versatile, cost-effective, require less energy to produce than alternative materials like metal or glass, and can be manufactured to have many different properties (North and Halden, 2013).

Plastic packaging of food products is a multibillion-dollar business (Akovali, 2007). Almost all processing companies around the world rely on the fact that plastic packaging preserves their products from spoilage, besides that transparent packaging allows the customer to view products without touching them (Siracusa et al., 2008). Current technologies aim to preserve the freshness and integrity of the food product while providing businesses with a cheap and efficient way to package their goods. In this regard, polymeric materials have replaced the traditional materials such as glass, paper, metal, etc. Currently, polyethylene terephthalate (PET), high-density polyethylene (HDPE), polyvinyl chloride (PVC), lowdensity polyethylene (LDPE), polypropylene (PP) and polystyrene (PS) are the main six plastics used to fabricate the packaging systems. The seventh type, denoted as 'other or $\mathrm{O}^{\prime}$, is made with a resin other than the above six, or is made of more than one resin used in combination. Polycarbonate (PC) and styrene/acrylonitrile (SAN) copolymer are examples for 'O'. These types have been used in food packaging, beverages and bottled water, as well as coatings of metallic cans of these products, with variation among these packaging plastics. 
For the purpose of plastics recycling, a product of each plastic of the above types should carry the 'resin identification code' (ranging from no. 1 to no. 7, in the same order these plastics are mentioned above), and is located in the center of the triangular recycle symbol. The symbol is usually imprinted on the surface of the plastic container. It does not mean that the packaging material is made from a recycled plastic, nor does it mean the plastic is recyclable. It only indicates the type of plastic resin, to help in sorting the different plastics of household products for the purpose of recycling.

Although recycling addresses the solid waste of plastics, another serious environmental problem, which is unseen and intangible, is the leachability of plastics (Guart, et al., 2011). Migration of chemical compounds, such as bisphenol A, nonylphenol and octylphenol, phthalates, styrene monomers, dimers and oligmers, and degradation or reaction products, and even heavy metals, such as cadmium, tin, lead, etc, from these plastics into food, has become a growing concern (Alin and Hakkarainen, 2012; Bradley et al., 2009). These various chemical migrants would certainly lead to organoleptic changes and/or contamination of soft drinks or bottled water and packaged food products, especially if these products are fat-enriched (Kappenstein, et al., 2012; Guart, et al., 2011; Kawamura, 2010; Ahmad and Bajahlan, 2007). Some of these migrants were proved to be environmental xenoestrogens or endocrine disruptors (North and Halden, 2013; Kawamura, 2010). Of course, this phenomenon of plastic additive migration has prompted a number of scientists into searching for new and safer packaging materials to replace the present plastics (Thakur, et al., 2013).

Determining the extent of plastics' use by food industry, the present study was carried out with the aim of verifying the prevalence of
PET, used in packaging of various food products, as well as testing its leachability to the heavy metal $\mathrm{Sb}$, taking bottled drinking water as an example for packaged foods and drinks found in the local market.

\section{Methods}

A number of superstores were selected randomly from different parts of Jeddah city, where diverse plastic-packaged food items have been checked and classified according to the plastic type used in their packaging, using the plastic code number observed inside the triangular recycle symbol imprinted on each item. 156 different food items were checked, covering various products, such as cooking oils, milk, soft drinks, cheese, etc.

Based on the results of the use extent of these plastics, PET was selected as another aspect of this study, due to its prevalence in food packaging. Eight brands of PET-bottled drinking water, representing main producing firms in Jeddah city, were used. The samples were procured on the same day, from major supermarket stores. Production date of these brands was similar, and each brand's expiry date was set at one year. The water bottles were of similar shape and volume $(0.251)$. Collectively, a total of 24 water bottles ( 8 brands x 3 bottles) were used in this study.

The $\mathrm{Sb}$ content was determined in the samples, within 2-6 h of purchase, according to the following protocol: on the day samples were procured, analysis of all brands (one bottle each) for $\mathrm{Sb}$ was performed and regarded as time-zero concentration (initial). Two more intact bottles from each brand were subjected to two conditions, starting from the same day of initial analysis. One bottle from each brand was stored at room temperature $\left(23 \pm 2^{\mathrm{O}} \mathrm{C}\right)$ and the other in the incubator (Fisher Scientific Company, Model 116D, USA; $50 \pm 2^{\mathrm{O}} \mathrm{C}$ ). Storage of the two bottles under both conditions continued for 6 months. 
Any sort of contamination or damage of bottles during storage and analytical procedure was strictly avoided.

Reagents used were of analytical grade. Glassware (conical flasks, test tubes and pipettes) used were treated by dilute $(1: 1)$ nitric acid and then rinsed with deionized water before use. Deionized water (Millipore, Molsheim, France) was used to prepare dilute concentrated nitric acid (37\%; $\mathrm{BDH}$ Chemicals Ltd.), calibration blanks and $\mathrm{Sb}$ standards from the stock solution (Inorganic Ventures Company, USA). Concentrated nitric acid was added (by $2 \%$ ) to the blanks and all samples prior to analysis and allowed to equilibrate at room temperature for 2 hours, followed by well hand shaking to homogenize each sample. By the end of the storage time, samples were analyzed for $\mathrm{Sb}$.

Analysis of samples was run with Inductively Coupled Plasma-Optical Emission Spectrometer (ICP-OES) -Varian Inc., USA. Three replicates of $10-\mathrm{mL}$ aliquot from blanks and each brand's bottle were sampled for each $\mathrm{Sb}$ analysis.

Data obtained for both investigations was subjected to statistical analysis. Results of use extent by food industry of the 7 plastics were analyzed and plotted with Microsoft Excel 2010 (Jelen, 2011), in terms of the percentage of food items packaged in each plastic type relative to the total number of food items examined.

Split plot design (SAS) was applied to analyze the $\mathrm{Sb}$ levels in the PET-bottled water samples, where the main plot treatments are the treatment conditions applied, and the eight brands analyzed were considered as subplot treatments (El-Nakhlawy, 2010).

\section{Results}

Fig. 1 presents percentage of items for each plastic type of packaged food products, relative to the total number of items examined, as identified by their imprinted polymer code. It should be noted that similar packaged food items from different companies were considered as different, even the plastic type is the same, since this investigation focused the extent of use of these plastics by food industry. The result indicated that plastic containers and bottles made of PET represent the most prevalent packaging polymeric material (42.95\%), followed by PP (20.51\%) and HDPE (17.31\%). PS, O (Other), LDPE and PVC were the least common types $(4.49 \%, 2.56 \%, 1.28 \%$ and $0.64 \%$, respectively). Plastic packages or bottles that were found to have no code represent a considerable percentage (10.26\%), and thus, their resins were unidentifiable.

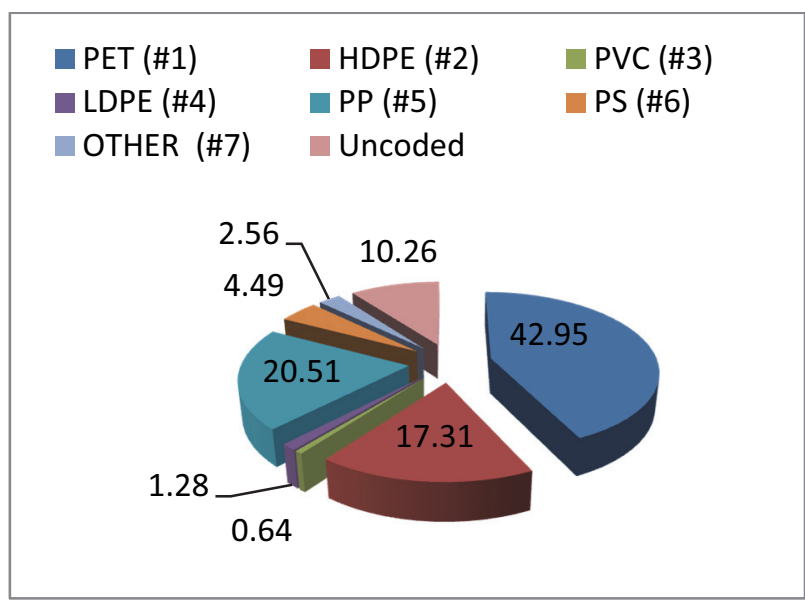

Fig. 1. Percentage of industrial use of the specified plastic types used in food packaging, indicating the PET prevalence among these types.

Table 1 shows $\mathrm{Sb}$ mean levels obtained from raw data of 3 replicate analyses for the 8 brands of the PET-bottled water under the specified conditions applied, compared with time-zero level. One-way analysis of variance (ANOVA) for data indicated highly significant $(\mathrm{p} \leq 0.0001)$ effects of temperature and storage time on PET leachability for Sb. A good comparison between these brands' bottledwater samples, with regard to their reactivity to the experiment conditions as a whole, can 
also be seen in Fig. 2, where the difference among some of them was significant $(\mathrm{p} \leq$ 0.05).

Table 1. Means \pm SD of antimony $(\mathrm{Sb})$ concentration $(\mu \mathrm{g}$ $\mathrm{L}^{-1}$ ) in PET-bottled-water of 8 Brands under two conditions applied for 6-month, compared with time-zero ${ }^{\uparrow}$ level of the element.

\begin{tabular}{|c|c|c|c|}
\hline $\begin{array}{c}\text { Brand } \\
\text { Symbol }\end{array}$ & $\begin{array}{c}\text { Time-zero } \\
\left(23^{\circ} \mathrm{C}\right)\end{array}$ & $\begin{array}{c}\text { Room } \\
\text { temperature }(23 \\
\left.{ }^{\circ} \mathrm{C}\right)\end{array}$ & $\begin{array}{c}\text { Incubator } \\
\left(50{ }^{\circ} \mathrm{C}\right)\end{array}$ \\
\hline B1 & 0.052 & 0.119 & 0.150 \\
\hline B2 & 0.048 & 0.119 & 0.787 \\
\hline B3 & 0.049 & 0.168 & 0.696 \\
\hline B4 & 0.060 & 0.118 & 0.311 \\
\hline B5 & 0.052 & 0.125 & 0.128 \\
\hline B6 & 0.051 & 0.160 & 0.763 \\
\hline B7 & 0.046 & 0.152 & 0.717 \\
\hline B8 & 0.069 & 0.128 & 0.907 \\
\hline Mean & 0.053 & 0.136 & 0.557 \\
\pm SD $* *$ & $\pm 0.008^{\mathrm{c}}$ & $\pm 0.020^{\mathrm{b}}$ & $\pm 0.298^{\mathrm{a}}$ \\
\hline
\end{tabular}

"On the day samples were procured to the laboratory.

** Highly Significant difference ( $\mathrm{p} \leq 0.0001)$ at LSD 0.0161 ; means followed by different superscripts are significantly different.

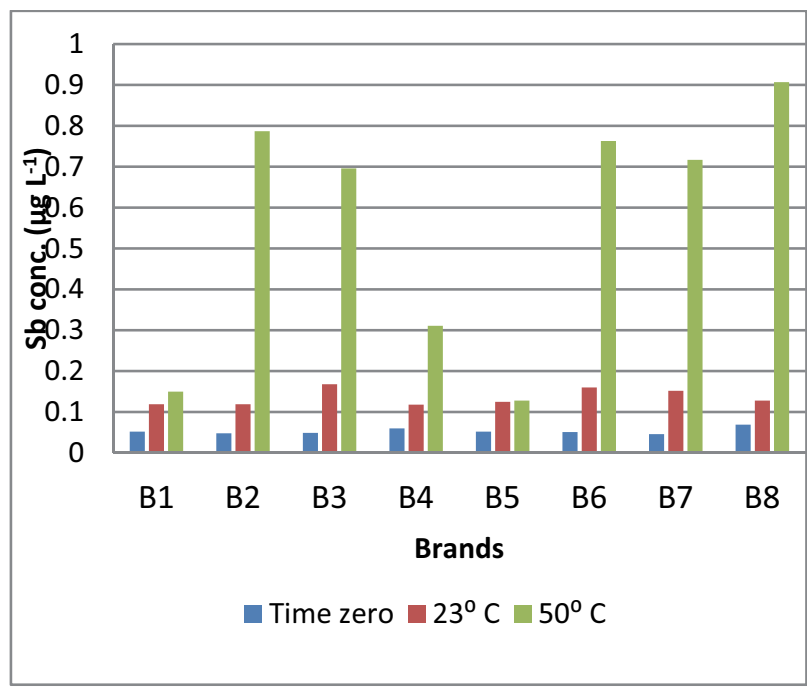

Fig. 2. Response of the 8 Brands' PET-bottled-water to the experiment conditions applied for 6-month, expressed in antimony (Sb) level $\left(\mu \mathrm{gL}^{-1}\right)$ for each Brand at each condition, compared with time zero.

\section{Discussion}

Since all of the other plastic types have been proved to be leachable by extensive research (Simoneau et al. 2012; Beldi et al., 2012; Alin and Hakkarainen, 2011; Lithner et al., 2011; Reingruber and Buchberger, 2010; Dopico-García et al., 2007; Al-Khatim and ElTom, 2006), most of the food processing companies have turned to PET to package their food products, of either aqueous or fatty contents. Based on an inflated publicity that PET is a non-leachable and safe plastic, many consider PET as a plastic of choice, which might explain the ubiquitous use of PET in food packaging, as manifested by this study.

According to researchers, PET is not an exception, with regard to the chemical migration phenomenon in plastics. In PETbottled water, Bach et al. (2013) could detect plastic migrating agents including formaldehyde, acetaldehyde, 2,4-di-tertbutylphenol (a degradation product of phenolic antioxidant stabilizers), as well as the intermediary monomer of bis(2hydroxyethyl)terephthalate.

Cirillo et al. (2013) detected the two plasticizers di-n-butylphthalate (DBP) and di(2-ethylhexylphthalate (DEHP) in PETpackaged ready-to-eat meals. Moreover, both of these research teams indicated that the concentration of migrating agents increased with storage time. Exposure to microwave or extreme conditions were shown by Cheng et al. (2010) and Westerhoff, et al. (2008) to enhance PET leachability. In the present study, temperature and storage time have both enhanced $\mathrm{Sb}$ release from the investigated PET into bottled drinking water, which is marketed locally at a large scale. The present results, in this regard, confirm the findings of these scientists and invalidate the claims praising PET as an unleachable plastic and safe for packaging of food products.

It should be noted that the maximum contaminant level (MCL) for $\mathrm{Sb}$ in bottled drinking-water in Japan is $2 \mu \mathrm{g} \mathrm{L}-1$, while in EU, USA, and Canada is observed at $5 \mu \mathrm{g} \mathrm{L}-1, \quad 6 \mu \mathrm{g} \mathrm{L}-1, \quad$ and $\quad 6 \mu \mathrm{g} \mathrm{L}-1$, 
respectively (Andra et al. 2012). Although results of the present study indicated lower levels for $\mathrm{Sb}$ than these standards, extension of storage under extreme conditions can enhance $\mathrm{Sb}$ leachability to levels that may induce adverse health effects. According to Shotyk and Krachler (2007), Sb, in the form of its trioxide $\left(\mathrm{Sb}_{2} \mathrm{O}_{3}\right)$, is the preferred polycondensation catalyst in PET fabrication. Antimony, in this trivalent species, has been shown to be more toxic than its pentavalent ones due to high affinity for sulfhydryl group in some biological molecules, such as sulfurcontaining proteins (Sundar and Chakravarty, 2010). Such affinity can lead to enzyme inhibition (Beyersmann and Hartwig, 2008).

Summertime temperatures inside enclosed cars, garages, and enclosed storage areas can exceed 50 degrees $\mathrm{C}$ in this city and other areas in Saudi Arabia as well. Such extreme conditions can promote leaching of antimony and other chemical agents from PET bottles or packages.

\section{Conclusions and Recommendations}

Classification of plastics used in packaging systems by food industry indicated the prevalence of PET over the other types. Despite belief that PET is unleachable and safe, this study has shown that PET, like other plastics, can leach toxic chemical agents, such as antimony. Of course, it would be impractical to phase out PET or the other types from people's daily life, but awareness of the nature of plastics and the health effects they might pose, due to leachability, should be promoted. Such effects can be averted if consumers use the freshly packaged water and avoid its storage for extended periods of time or expose them to high temperatures.

\section{References}

Ahmad, M. and Bajahlan, A.S. (2007) Leaching of styrene and other aromatic compounds in drinking water from PS bottles. J Environ Sci (China), 9 (4): 421-6.
Akovali, G. (2007) Plastics, rubber, and health. Chap 5, p. 109. iSmithers Rapra Publishing, London.

Alin, J. and Hakkarainen, M. (2012) Migration from polycarbonate packaging to food simulants during microwave heating. Polymer Degradation and Stability, 97 (8): 1387-1395.

Alin, J. and Hakkarainen, M. (2011) Microwave heating causes rapid degradation of antioxidants in polypropylene packaging, leading to greatly increased specific migration to food simulants as shown by ESI-MS and GC-MS. J Agric Food Chem., 59 (10): 5418-27.

Al-Khatim, A.A. and Ali, K.E. (2006) Effects of chemical migrants from two widely used plastics on reproduction in mice. Health Science, 52, (4): 397-405.

Andra, S.S., Makrisa, K.C., Shineb, J.P. and Lub, C. (2012) Co-leaching of brominated compounds and $\mathrm{Sb}$ from bottled water. Environment International, $\mathbf{3 8}$ (1): 45-53

Bach, C., Dauchy, X., Severin, I., Munoz, J.F., Etienne, S. and Chagnon, M.C. (2013) Effect of temperature on the release of intentionally and non-intentionally added substances from polyethyleneterephthalate (PET) bottles into water: chemical analysis and potential toxicity. Food Chem.,139 (1-4): 672-80.

Beldì, G., Pastorelli, S., Franchini, F. and Simoneau, C. (2012) Time- and temperature-dependent migration studies of Irganox 1076 from plastics into foods and food simulants. Food Addit Contam Part A, 29 (5): 836-45.

Beyersmann, D. and Hartwig, A. (2008) Carcinogenic metal compounds: recent insight into molecular and cellular mechanisms. Arch Toxicol, 82: 493-512.

Bradley, E.L., Castle, L., Jickells, S.M., Mountfort, K.A, and Read, W.A. (2009) Use of overall migration methodology to test for food-contact substances with specific migration limits. Food Addit Contam Part A, 26 (4): 574-82.

Cheng, X., Shi, H., Adams, C.D. and Ma, Y. (2010). Assessment of metal contaminations leaching out from recycling plastic bottles upon treatments. Environ Sci Pollut Res Int, 17 (7): 1323-30.

Cirillo, T., Fasano, E., Esposito, F., Del Prete, E. and Cocchieri, R.A. (2013) Study on the influence of temperature, storage time and packaging type on di-nbutylphthalate and di(2-ethylhexyl)phthalate release into packed meals. Food Addit Contam Part A, 30 (2): 403-11.

Dopico-García, M.S., López-Vilariñó, J.M. and GonzalezRodríguez, M.V. (2007) Antioxidant content of and migration from commercial polyethylene, polypropylene, and polyvinyl chloride packages. Agric Food Chem, 55 (8): 3225-31.

El-Nakhlawy, F.S. (2010). Experimental design and analysis in scientific research. Sci. Pub. Center, King Abdulaziz University, Jeddah, Saudi Arabia. p. 284. 
Guart, A., Bono-Blay, F., Borrell, A. and Lacorte, S. (2011). Migration of plasticizers phthalates, bisphenol A and alkylphenols from plastic containers and evaluation of risk. Food Addit Contam Part A, 28 (5): 676-85.

Jelen, B. (2011) Charts and Graphs: Microsoft Excel 2010 Chap 5. Que Publishing, Indianapolis, Indiana, USA.

Kappenstein, O., Vieth, B., Luch, A. and Pfaff, K. (2012) Toxicologically relevant phthalates in food. EXS, 101: 87106.

Kawamura, M. (2010). Endocrine disruptors in food contact articles and baby toys with their transition. Bulletin of National Institute of Health Sciences, 128: 17-26.

Lithner, D., Nordensvan, I. and Dave, G. (2012) Comparative acute toxicity of leachates from plastic products made of polypropylene, polyethylene, PVC, acrylonitrile-butadiene-styrene, and epoxy to Daphnia magna. Environ Sci Pollut Res Int, 19(5):1763-72.

North, E.J. and Halden, R.U. (2013). Plastics and environmental health: the road ahead. Rev Environ Health. 28 (1): 1-8.

Reingruber, E. and Buchberger, W. (2010) Analysis of polyolefin stabilizers and their degradation products. $J$ Sep Sci., 33 (22): 3463-75.
Shotyk, W. and Krachler, M. (2007) Contamination of bottled waters with Sbleaching from polyethylene terephthalate PET) increases upon storage. Environ Sci Technol. 41(5):1560-3.

Simoneau, C., Van den Eede, L. and Valzacchi, S. (2012) Identification and quantification of the migration of chemicals from plastic baby bottles used as substitutes for polycarbonate. Food Addit Contam Part A, 29 (3): 46980 .

Siracusa, V., Rocculi, P., Romani, S. and Dalla Rosa, M. (2008) Biodegradable polymers for food packaging: a review. Trends in Food Science \& Technology, 19 (12): 634-643.

Sundar, S. and Chakravarty, J. (2010) Antimony toxicity, Int J Environ Res Public Health, 7 (12): 4267-4277.

Thakur, V.K., Thakur, M.K. and Gupta, R.K. (2013) Synthesis of lignocellulosic polymer with improved chemical resistance through free radical polymerization, Int. J. Biol. Macromolec., 61: 121-126.

Westerhoff, P., Prapaipong, P., Shock, E. and Hillaireau, A. (2008) Antimony leaching from polyethylene terephthalate (PET) plastic used for bottled drinking water, Water Res., 42: 551-556. 


\section{التحقق من انتشار بلاستيك PET في التعبئة الغذائية و اختبار ارنشاحيته لعنصر الأنتمون في مباه الثرب المعبأة}

\section{السر عبدالقادر الخاتم ومحمد حمد شيبوب}

كلبة الأرصاد والبيئة وزراعة المناطق الجافة، قسم العلوم البيئية (صحية البيئة)، جامعة الملك عبدالعزيز، جلة، المدلكة العربية السعودية

الستخلص. في الوقت الحاضر يعتبر بلاستيك الــ PET هو المفضل في التعبئة الغذائية. فهناك زعم

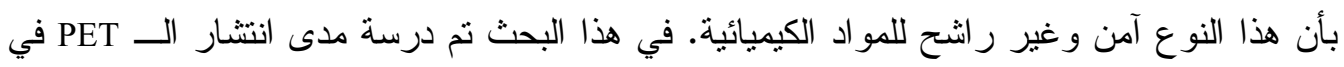

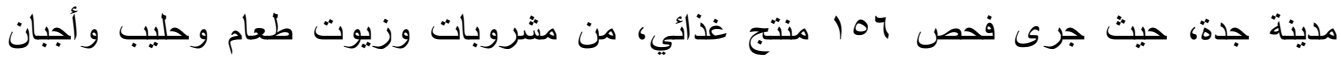
وغير ها، يتم تسويقه معبأ في حاوية أو قارورة بلاستيكية، وذللك في عدد من الدحال التجارية الكبرى

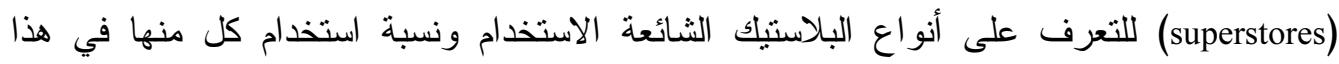
الجانب. تم ذلك من خلال رقم التصنيف (identification code) الخاص بكل نوع منها ، حيث يوجد التال

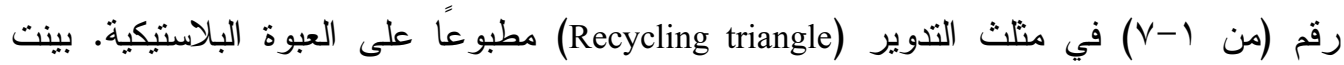

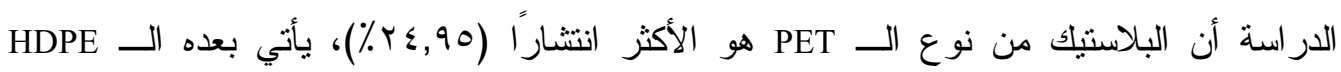

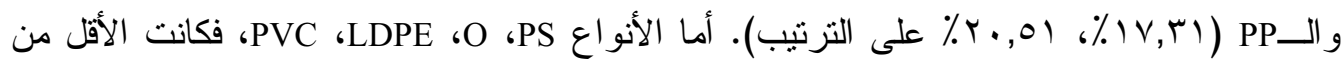

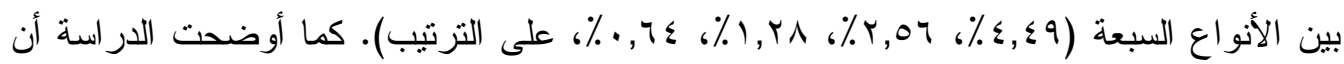

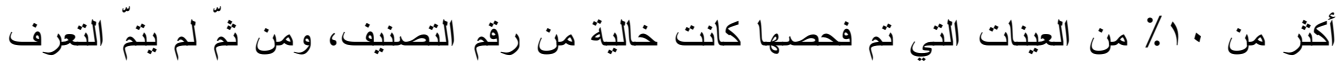

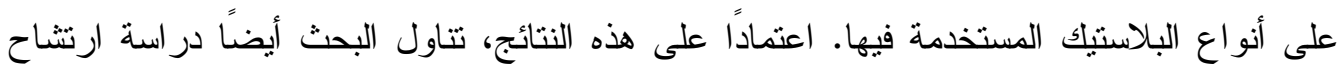

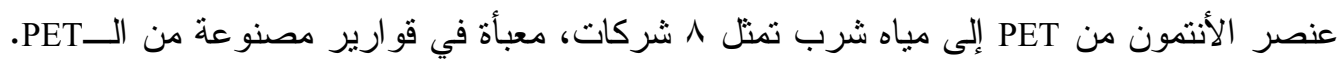

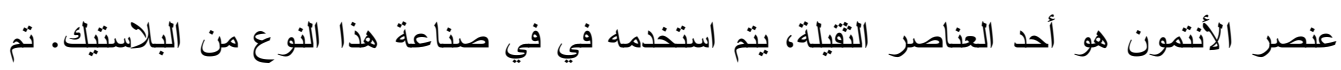

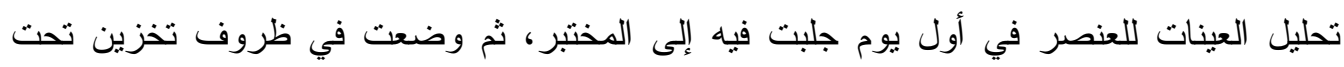

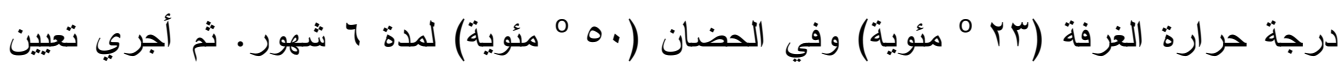

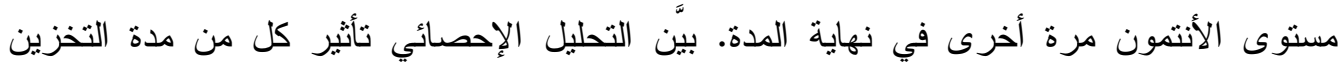

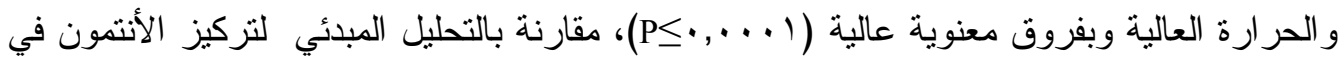


